\title{
THE BYZANTINE MASCULINITY AT WAR: AN APPROACH ON THE MANLINESS OF THE ARMY IN THE MIDDLE BYZANTINE ERA
}

\author{
Dr. Marilia Lykaki \\ National and Kapodistrian University of Athens. Grecia.
}

\begin{abstract}
As a social phenomenon war affects soldiers and civilians, men and women. The present contribution aims to examine various conceptions of masculinities within a military context during the Middle Byzantine Era. The identity of the Byzantine soldier is tightly connected with a specific type of masculinity that is derived from the Roman past and the Christian religion. The evolution of the military system during the middle era creates new types of soldiers that are called to oppose the powerful enemies of the Empire. Victorious engagements, typically result in moral principles that are in contrast with those found while in state of defeat. Thus, in this study, special attention will be given to the soldiers' identity and behaviour during their captivity. It is interesting to explore how that transitional situation affects the characteristics of the Middle Byzantine combatant masculinity.
\end{abstract}

Keywords: Byzantine history - Byzantine Empire - masculinity - war - Christianity - soldiers - captives.

\section{LA MASCULINIDAD BIZANTINA EN LA GUERRA: UNA APROXIMACIÓN A LA VIRILIDAD DEL EJÉRCITO EN LA ÉPOCA MEDIO BIZANTINA}

Resumen: Como fenómeno social, la guerra afecta a soldados y civiles, hombres y mujeres. La presente contribución tiene como objetivo examinar varias concepciones de las masculinidades dentro de un contexto militar durante la Época Medio Bizantina. La identidad del soldado bizantino está estrechamente relacionada con un tipo específico de masculinidad que se deriva del pasado romano y la religión cristiana. La evolución del sistema militar durante la época media crea nuevos tipos de soldados que están llamados a oponerse a los poderosos enemigos del imperio. Los compromisos victoriosos, por lo general, resultan en principios morales que contrastan con los encontrados en la condición de derrota. Por tanto, en este estudio se prestará especial atención a la identidad y el comportamiento de los soldados durante su cautiverio. Es interesante explorar cómo esa situación 
de transición afecta las características de la masculinidad combatiente bizantina media.

Palabras clave: Historia bizantina - Imperio bizantino - masculinidad - guerra cristiandad - soldados - cautivos.

\section{Recibido: 18.11.2019 - Aceptado: 27.04.2020}

\section{Correspondencia: Dr Marilia Lykaki}

Email: mlykaki@arch.uoa.gr

Postdoctoral researcher. National and

Kapodistrian University of Athens, Greece.

Faculty of History and Archaeology, School of Philosophy

Panepistimioupoli Campus, Zografou 15772.

he approach of masculinity as an analytical category in
historical research often raises discord among historians ${ }^{1}$.
Particularly in the field of Byzantine History, the relevant studies are scarce and masculinity is often not their main question, but results from the study of other subjects. This paper attempts to contribute to this field by focusing, however, in various perceptions of masculinity within a military context during the Middle Byzantine Era.

Even though medieval society had drawn up distinct gender behavior for men and women, war as a social phenomenon affects allmen and women, soldiers and civilians. The identity of the Byzantine soldier is inextricably intertwined with a specific type of masculinity that is derived from the Roman past and the Christian religion. The evolution of the military system during the middle era creates new types of soldiers that are called to oppose the powerful enemies of the Empire. Victorious engagements typically result in moral principles that are in contrast to those found while in a state of defeat. Thus, in this study, special attention will be given to cases that reflect soldiers' identity and behaviour before battle or during captivity. Captivity is a transitional situation that could lead either

1 M.E. Stewart, (2014), Some Disputes Surrounding Masculinity as a Legitimate Category of Historical Inquiry in the study of Late Antiquity", Masculinities 1, 77-91. 
to freedom or slavery. Therefore, it is interesting to explore, how captivity affects the characteristics of the Middle Byzantine combatant masculinity. Primary byzantine sources, historiographical, hagiological and military manuals, along with modern studies are integrated, in order to create a greater sense of how middle byzantine secular and ecclesiastical writers linked representations of military valor to their notions of the qualities that mirrored manliness.

Initially, we need to define the notion of masculinity and gender, as it will be analyzed in this paper. As a tool of research, rather than the biological differences of sex, gender refers to the differences between men and women in terms of the differences created by societies ${ }^{2}$. Therefore, it can be considered as a social construction, which means that one's perception of the world or of ideas develops through interaction with the society that surrounds him. Therefore, the social environment in which one grows up and lives plays a decisive role in how one assumes such a flexible concept as masculinity. The biological and social dimensions are not identical, nor can they be separated, as the changes within society give meaning to biological characteristics, a necessary condition for the existence of societies. It follows from the above that the discussion for the history of masculinity needs to be further expanded to include a fuller analysis of its interaction with other determinants of status. In particular, concerning the question of manliness and war, it cannot be fully understood until we know more about the range of alternatives available to men and the processes by which they shaped and were shaped by relations of power between men and between men and women. This requires an approach to masculinity through variant categories such as class, age, marital status, ethnicity and religious identity ${ }^{3}$.

In recent years, the study of gender has moved away from the longer narratives, while interest has shifted from the impersonal structures and mechanisms of power to everyday life, to the subjectivity of experience, and to the tactics for the management of power. Gender is a component of social relations, based on the perceptible differences between the

2 L. James (ed.), (1997), Women, Men, and Eunuchs. Gender in Byzantium, London - New York, Introduction, p. xvii.

3 Karen Harvey - Alexandra Shepard, (April 2005), What Have Historians Done with Masculinity? Reflections on Five Centuries of British History, circa 1500-1950, Journal of British Studies 44, p. 274-280. 
genders and is a primary manner for making sense of power relations ${ }^{4}$. Such a research aims at the historicization of manhood as an experience, as a mental process or action, as a cultural representation or performance. Thus, manhood is primarily a gender-based relationship rather than a fixed category or identity, formed hierarchically in relation to and through a negotiation not only with "femininity", but also as to a series of different male models, in its entanglement with other types of differences, as it is already been sed.

How gender is understood articulates the values of a society and therefore its ideas of order ${ }^{5}$ and what should be striven for. Especially for the byzantine period the approach through gender helps to illuminate foundational values of the society between Greek-Roman and Christian attitudes to the body and spirit, and between Christian aspirations and the values of the Byzantine world from Late Antiquity to the Late Byzantine Era $^{6}$. If there are archetypes in the male image, they must be largely culturally constructed as symbolic systems, not simply as products of anatomy, because anatomy determines little in those contexts where the moral imagination gets involved ${ }^{7}$. This is the meeting point where the discussion about manliness meets with the studies on war as a social and cultural phenomenon. Even if during belligerent situations civilians also take action $^{8}$ the principle actors are the military forces. Manliness has

4 J.W. Scott, (1986), Gender: A Useful Category of Historical Analysis, American Historical Review, 91 (5), p. 1053-1075; repr. in (1988), J. W. Scott, Gender and the Politics of History, New York, p. 28-50.

5 R.F. Taft, (1998), Women at Church in Byzantium: Where, When And Why?, Dumbarton Oaks Papers, 52, p. 27-87; repr. in (2001), R.F. Taft, Divine Liturgies: Human Problems in Byzantium, Armenia, Syria and Palestine, Aldershot, I.

6 D. Casey, (2013), The Spiritual Valency of Gender in Byzantine Society, in B. Neil - L. Garland (eds.), Questions of Gender in Byzantine Society, Surrey.

7 D.D. Gilmore, (1990), Manhood in the Making: Cultural Concepts of Masculinity, New Haven, p.23.

It is interesting that when the writers refer to women who had to participate in a combat, for instance during the conquest of their own city, they

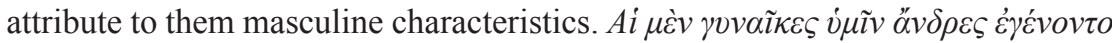
(women became men ) is an indicative example from Eustathius of Thessaloniki, ed. St. Kyriakides, Eustazio di Thessalonica, La espugnazione di Thessalonica 
always been a synonym of the army. And the latter has always been a matter of vital importance for the Eastern Roman Empire as its existence has often been judged in the battlefields. "The army is for the state what the head is for the body" according to a $10^{\text {th }} \mathrm{c}$. Novella that gives the essence of the idea of the army. Furthermore, it is "the glory of the emperor and the force of the palace" according to the $11^{\text {th }} \mathrm{c}$. author Kekaumenos in his Strategikon, a manual on military and household affairs ${ }^{10}$. Spread initially over three continents and then two continents, the empire had to simultaneously deal with attacks on numerous fronts. So, beyond its highly sophisticated diplomacy, it also required a large and capable army and fleet. I believe it is true that — as is often said - military organization along with law are the points of the Roman heritage for which the Byzantine Empire became the most faithful heir and follower. In the middle era, changes occurred in the defense which further reinforced it as it faced the particularly powerful enemies appearing in the north and, mainly, the eastern front. The empire was served by various soldiers who could be classified according to their relationship with the central authority and the way in which they were recruited. Therefore, next to the imperial tagmatic units were self-supporting thematic militia, full-time theme soldiers supported by state salaries and other emoluments ${ }^{11}$ and mercenaries, professionals

[Insituto Siciliano di Studi Byzantini e Neoellenici, Testi e Monumenti, Testi 5], Palermo 1961, p.90 ${ }_{16}$ Several cases also in Ioannis Caminiatae De expugatione Thessalonicae, ed. G. Böhlig [CFHB 4], Berlin-N. York 1973.

9 J. Zepos and P. Zepos (ed.) (p. C.E. von Z. Lingenthal), Novellae et Aurae Bullae imperatorum post Justinianum, «Jus Graecoromanum» 1, Aalen:

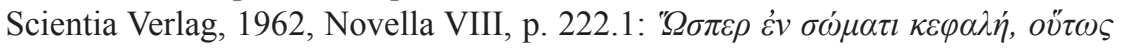

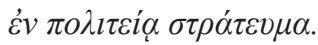

10 Kekaumenos, Strategikon, ed. G. Litavrin, Sovety i rasskazy Kekavmena: pouchenie vizantiǔskogo polkovodtca XI veka, Saint-Pétersbourg 2003 (hereafter:

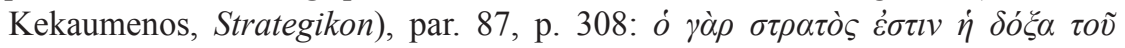

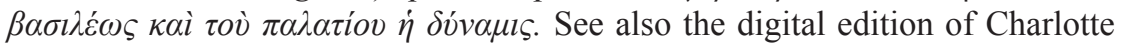
Roueché : http://www.ancientwisdoms.ac.uk/library/kekaumenos-consilia-etnarrationes.

11 There is an extensive bibliography on the thematic army. See: A. Pertusi, (1958), La formation des thèmes byzantins, in: Berichte zum XI. Internationalen Byzantinisten-Kongress, München, 1-40; Haldon J.F., (1979), Recruitment and Conscription in the Byzantine Army, c.550-950. A Study on the Origins of the 
recruited for particular regiments or for particular campaigns that became more and more employed during the $11^{\text {th }}$ century and the late Byzantine era $^{12}$. Especially the farmer - soldier correlation, part of the thematic army, certainly added to the military profile characteristics of a manliness closer to ordinary men. Unfortunately, on the middle and upper levels of officers, the sources are not sparing. Although it seems to exist a substantial meritocratic element, by the middle of the 11th century Byzantium saw the growth of a powerful provincial aristocracy that itself provided a major source of recruits to the middle and senior officers' positions ${ }^{13}$.

Byzantine sources often seem to attribute a different ethos to the soldiers of these different groups. Mercenary troops are reproached for

Stratiotika Ktemata [Österreichische Akademie der Wissenschaften, philos. - hist.Klasse, Sitzungsberichte, 357], Wien; Haldon J., Cameron Averil., (1995), Seventh-Century Continuities : the Arab and the "Thematic Myth", in : States, Resources, Armies [The Byzantine and Islamic Near East, 3 /Studies in Late Antiquity and Early Islam, 1], Princeton, 379-423; Vassiliki Vlyssidoy et als, (1998), Asia Minor and Its Themes: Studies on the Geography and Prosopography of the Byzantine Themes of Asia Minor (7th-llth Century). In Greek [Research Series, 1], National Hellenic Research Foundation, Institute for Byzantine Research, Athens; C. Zuckerman, (2005), Learning from the Enemy and More: Studies in "Dark Centuries" Byzantium, Millennium 2, p. 125f ; Efi Ragia, (2012), The Geography of the Provincial Administration of the Byzantine Empire (ca.600-1200): I.3 Apothekai of Africa and Sicily, Final Notes and Conclusions", Eoa kai Esperia 8 (2012), p. 113-144.

12 J. Shepard, (1993), The uses of the Franks in 11th century Byzantium, Anglo-Norman Studies 15, p. 280-281; G. Theotokis, (2012), Rus, Varangian and Frankish mercenaries in the service of the Byzantine emperors (9th - 11th c.). Numbers, organization and battle tactics in the operational theatres of Asia

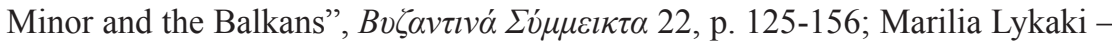
Nafsika Vassilopoulou, (2018), Mercenaries of Byzantium: Their role during the transition from the Middle to the Late Byzantine era, in: A. Kolia-Dermitzaki, V. Seirinidou, Sp. Ploumidis (ed.), M. Lykaki (colab.), Histories of War in South-Eastern Europe: An Approach in the Longue Durée. A centenary since the Balkan Wars of 1912-13. International Scientific Conference of the Department of History and Archaeology (7-9 November 2013), Athens, p. 160-175, with large bibliography on the subject. 
their opportunism and betrayal of principles ${ }^{14}$. Besides, the observance of discipline imposed by the Byzantine defense system considered boldness punishable ${ }^{15}$. There is no common attitude towards soldiers; in specific periods or in specific areas, soldiers are the defenders of their property and life, and for others the representatives of repression on behalf of the central government.

Life in the army involved a quite different sort of daily routine from life in a civilian context or from that in less disciplined and organized neighboring armies. The author of a $6^{\text {th }}$-century military handbook makes this abundantly clear: 'Nature produces but few brave men, whereas care and training make efficient soldiers' ${ }^{\prime 16}$. The use of the word $\dot{\alpha} \nu \delta \rho \varepsilon i \alpha$ and the changing significance that it may have for the middle byzantine writers illustrates, I believe, in some level, the ideal constructed for the perfect military leader and soldier. The notion of $\alpha \dot{\alpha} \delta \rho \varepsilon i ́ \alpha$ (andreia) - a word originating from $\alpha v \eta \dot{\varphi} \rho$ (man) as virtus is derived from vir (man)designates the activity and quality associated with the noun from which it is derived and characterizes the ideal behavior of a man. In addition, $\dot{\alpha} v \delta \rho \varepsilon i ́ \alpha$ holds a central part in war, politics and religion ${ }^{17}$. One of the primary terms for Greco-Roman conceptualisations of manhood, $\alpha v \delta \rho \varepsilon i ́ \alpha$, can mean either "manliness" or "courage", depending on the context used

14 See for exemple in George Pachymeris, ed. A. Failler, Georges Pachymérès Relations Historiques, IV Livres X-XII [CFHB 24/4], Institut Français d'Études Byzantines, Paris 1999, vol. IV, p. 529 ${ }_{14-16}, 529_{18-19}$ where he

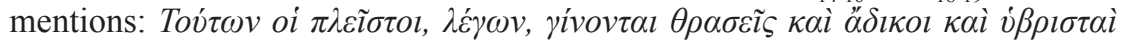

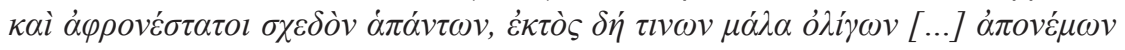

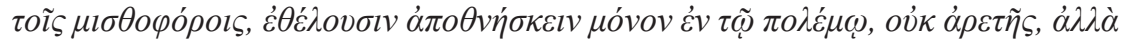
$\mu \imath \sigma \theta o \tilde{v} \chi \alpha ́ \rho \imath v$.

15 For instance, it was prohibited by the so-called Military Laws, the

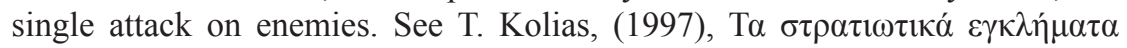

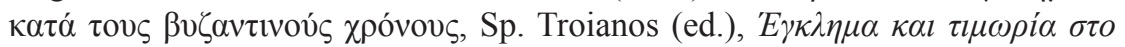
Bvढ̌́v $v \imath$, Athens, p. 295-316.

16 Das Strategikon des Maurikios, ed. G.T.Dennis, trans. E. Gamillscheg [CFHB, 17], Vienna 1981, vi, proem, 1; viii, B 9 ; J. Haldon, (1999), Warfare, State and Society in the Byzantine World 565-1204 [Warfare and History] London (hereafter: Haldon, Warfare), p. 265.

17 A. Myles-McDonnell, (2006), Roman manliness: virtus and the Roman Republic, Cambridge, p. 75. 
by the author ${ }^{18}$.

The changes that had taken place from the early to the middle Byzantine era also brought changes to the male role model and to the manners of acquiring and perceiving the concept of bravery, which often accompanies gallantry, prudence and wisdom. As Attaleiates states that the noble Romans were fighting for glory and courage and to save their homeland and its greatness and not for material motives ${ }^{19}$.

In particular, the intellectual growth and the spreading of Christianity during the period under investigation have ended up shaping the medieval world and beyond. Nevertheless, it is important to keep in mind that, even the changes in the forms of masculinity are never wholly assimilated by individuals but are in dialog with earlier — often conflicting — social and cultural scripts ${ }^{20}$. But, as Mark Bloch has pointed out, it is to the great despair of historians, men failed to change their vocabulary every time they change their customs ${ }^{21}$.

To shed light on soldiers' masculinities and investigate the subtleties of change, we need a closer analysis of individual or group experience

18 On war manliness in early byzantine era see the article of M. Stewart, (2006), Soldier's Life. Early Byzantine Masculinity and the Manliness of War, Byzantina Symeikta 26, p. 11-44.

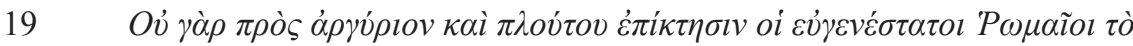

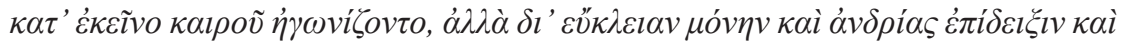

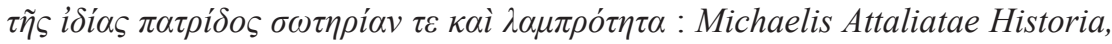
ed. Th.E. Tsolakis. [CFHB 50], Academia Atheniensis, Athens 2011 (hereafter: Attaleiates, Historia), p. 169-170. For the notion of 'andreia' in Attaleiates see also A. Kazhdan, (1984), The Social Views of Michael Attaleiates in: A. Kazhdan (ed.), S. Franklin (colab.), Studies on byzantine Literatureof the eleventh and Twelfth Centuries, Cambridge, p. 38-39; A. Kazhdan, Ann Wharton Epstein, (1985), Change in Byzantine Culture in the Eleventh and Twelfth Centuries, Berkley - Los Angeles.

20 According to R. W. Connell, (1995), Masculinities, Cambridge, p. 73, "any one masculinity, as a configuration of practice, is simultaneously positioned in a number of structures of relationship, which may be following different historical trajectories".

21 M. Bloch, (2006), Apologie pour l'histoire ou métier d'historien, in An. Becker - E. Bloch (eds), Marc Bloch. L'Histoire, la Guerre, la Résistance, Paris, p. 872 . 
before and after the battle. The narrative sources referring to the army's behavior as a whole fall short in numbers as to those individually pertaining to military officers. Byzantine historians do not find anonymous soldiers as interesting as military leaders - often with a noble origin and a glorious past in the battlefield ${ }^{22}$. Significance is given to the narration when it comes to the exploits of the emperor himself, such as Heraclius. Nonmartial byzantine emperors may have also promoted their own martial and masculine ideology, like the intellectual Constantinus VII Porphyrogenetus with his precious writings on strategy and army. Moving from the early to the middle period one must add to the masculinity of the ideal leader the qualities of piety, devotion to the emperor, noble origin, beauty and vigor. The patriarch Nikolaos I Mystikos in his Letters adds to the abovementioned meekness and wisdom ${ }^{23}$. Nikephoros Phokas, domestikos of the scholai, seems to concentrate those virtues at his time ${ }^{24}$. In the $12^{\text {th }}$ century the philanthropic attitude toward the soldiers or the defeated enemy and generosity complete the profile ${ }^{25}$.

22 R.-J. Lilie, (2013), Die byzantinische Gesellschaft im Spiegel ihrer Quellen», Zbornik radova Vizantološkog instituta 50, p. 959-968 ; Athina

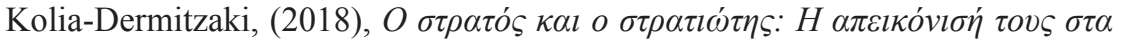

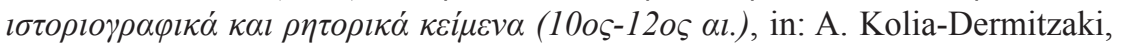
V. Seirinidou, Sp. Ploumidis (ed.), M. Lykaki (colab.), Histories of War in South-Eastern Europe: An Approach in the Longue Durée. A centenary since the Balkan Wars of 1912-13. International Scientific Conference of the Department of History and Archaeology (7-9 November 2013), Athens, p. 179-206.

23 Nicholas I, Patriarch of Constantinople, Letters, ed. R. J. H. Jenkins - L. G. Westerink [CFHB 6], Washington D.C. 1973, letter 80.

24 See Athina Kolia-Dermitzaki, (2012), About Virtue and Vice. The Byzantine Officials in Historiographical Sources, Part I, Political and Military Officials of the 9th and 10th Centuries, Athens (in Greek), p. 240-242.

25 For the $11^{\text {th }}$ and $12^{\text {th }}$ centuries in particular the subject is studied by

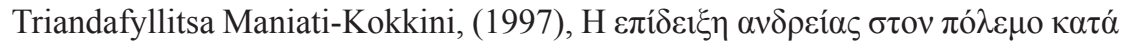

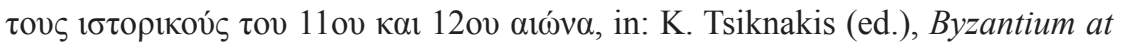

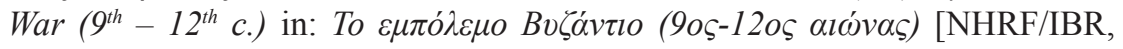
International Symposium 4], Athens, p. 239-259. The author also relates the terms used by the byzantine historians to investigate rather they thought more of the physical qualities than the spiritual virtues. But, while the moderate coexistence of these physical and mental strengths leads to courage, which is praised by historians, the mental qualities that lead to bravery are sometimes excessive, 
Nevertheless, frequent references are also made to soldiers as a whole, whose valor and gallantry contribute to victory. Of course, writers are sparing when it comes to anonymous soldiers, as Niketas Choniates states $^{26}$. The disgrace for cowardice in the battlefield rather understandably includes the ridicule of the great soldier as a "woman". There are plenty of cases of mutiny and unrest among the provincial armies and the examples of troops panicking when the commander was thought to have been killed or injured is evidence of the variable psychological condition of the troops ${ }^{27}$. Furthermore, brave undertakings are characterized as "manly" and "youthful" acts ${ }^{28}$. Beyond, however, the acclamation, the demonstration of valor could also lead to tangible gifts for the bravery of military men. ${ }^{29}$

Byzantine historians of the time, when narrating the frequent wars between the Byzantium and its neighbors or the "barbarian" raiders, directly and critically refer to the military virtues and to the group and personal performance of combatants. Sources, for example, when referring to the attempt by Emperor Basil II to move through the pass of Kleidion in 1014, state that the Bulgarian ruler Samuel had placed decent guardians who bravely resisted and fled only when General Nikephoros Xiphias ambushed them. Samuel himself escaped capture with the aid of his son Gabriel Romanos, who bravely received the attackers. This successor is characterized as stronger than his father but less wise ${ }^{30}$. For the byzantine author, the achievement of the byzantine general was greater because the enemy's soldiers were decent and brave.

Particular reference can be made to eunuchs, who have been the

becoming a disadvantage. Courage then becomes audacity or irrational boldness.

26 Nicetae Choniatae Historia, ed. J. A. van Dieten, [CFHB 11], Berlin New York, 1975, p. $187_{5}$. Haldon, Warfare, p. 264.

See for example Ioannis Skylitzae Synopsis Historiarum, ed. ThuRn [CFHB 5], Berlin-New York 1973 (hereafter: Skylitzes), p. 380 comments for Constantinos Dalassenos who was fleeing from the opponents during the expedition of Romanos III Argyros in Syria, causing great confusion and disorder in the army.

29 J.Cl. Cheynet, La politique militaire byzantine de Basile II à Alexis Coirmene, Zbornik Radova Vizantoloskog Instituta 29-30 (1991), p.69.

$$
\text { Skylitzes, p. } 348_{17}-349_{34,46-48} \text {. }
$$


subject of numerous studies ${ }^{31}$. Their frequent treatment by byzantine authors as individuals who had transgressed their gender construct is evidence of just how confirmed gender categories were within the byzantine culture. Eunuchs served in the army and could even rise to very high ranks ${ }^{32}$, except of course that of the emperor - which required an ablebodied individual. Such examples include Eutropius during the reign of Theodosius I and Arcadius, Narsis, the general of Justinian I, Theoctistus and Michael during the reign of Leo III, and many more. Basil II sent his most loyal eunuch, Orestis, on the campaign to Sicily, but sources blame him for the disastrous defeat, as he was so worthless and inexperienced in war that the bravery of the troops could not prevail ${ }^{33}$. Sources also mention, in 1047, ten generals from the noble and prudent and bravely martyred Saracens, noting, obviously in a negative demeanor, that the Emperor Constantine Monomachos placed eunuch Nikephoros, an old priest, in charge of the eastern battalions and the campaign, honoring him as raictor and military commander, not because he was engaged and active in warfare, but because he had the king's favor ${ }^{34}$. It is also said that, in 1030, an anonymous eunuch who was a ship's steward, in order to save his possessions during an Arab attack, fiercely stormed the enemies, while none of the generals and soldiers dared proceed in the name of bravery ${ }^{35}$.

31 Here some indicative titles: Liz James (ed.), (1997), Women, Men and Eunuchs: Gender in Byzantium, London-New York; M. Kuefler, (2001) The manly eunuch : masculinity, gender ambiguity, and Christian ideology in late antiquity, Chicago; Kathryn M. Ringrose, (2003), The Perfect Servant: Eunuchs and the Social Construction of Gender in Byzantium, Chicago; S.F Tougher, (2013), Bearding Byzantium: Masculinity, eunuchs and the Byzantine life course, in: N. Bronwen and L. Garland, Lynda (eds), Questions of Gender in Byzantine Society, Farnham, p. 153-166; Messis Ch., Les eunuques à Byzance, entre réalité et imaginaire [Dossiers Byzantins 14] Paris 2014.

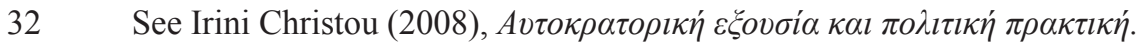

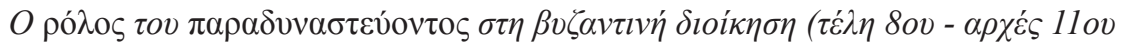
$\alpha \iota \omega ́ v \alpha)$, Athens.

33 Skylitzes, p. $368_{82-84}, 383_{97}-384_{10}$ See also Hélène Ahrweiler, (1966), Byzance et la mer, Paris 1966, p. 123.

34 Skylitzes, p. $444_{30-31}, 464_{13-19}$ and Nicéphore Bryennios, Histoire, ed. P. Gautier, [CFHB 9], Bruxelles 1975 (hereafter: Bryennios), p. $93_{1-5 .}$

Skylitzes, p. $381_{25-34 .}$ 
Moving on, important elements for exploring the question of manhood and whether it is influenced by the state of captivity can be found in cases of soldiers who were captured, although there is no homogenization of the conditions here, either. The approach to captured soldiers varied and depended on numerous factors, such as whether they were prominent officers or ordinary soldiers, what treaties had been reached and what practices had been established between the Byzantium and the rival holding the prisoners, whether they had some sort of expertise, thus making them useful to the opponent, and, of course, whether they had the intention of converting to another religion (as regards prisoners between Christians and Muslims). The Taktika of Leo VI advise the general: "Do not kill the prisoners before the end of the war, particularly those who are illustrious and important to the enemy. Keep in mind that fortune is fickle and victory may be overturned. Should some of your men be taken prisoner or one of your castles sacked, you will be able to exchange them ... and in return for the enemy prisoners you may take back your friends and allies. However, if the enemy does not wish to do that, you have every right to retaliate, acting according to your wishes so that you may harm the enemy"36. According to this, it seems that it could be an agreement with the enemy to exchange prisoners if that would be for the benefit of the Byzantines and especially the eminent and important to the enemy like highly ranked officers of the army or soldiers who could also serve as informants ${ }^{37}$. The following episode is indicative of the importance of soldiers as captives: during an exchange (allagion) in 846 the Byzantines refused to accept elderly men and women as well as very young children from the Muslim side because, as they were saying, the Muslim prisoners they had in their possession for exchange were all soldiers ${ }^{38}$.

In addition, captivity could be a situation that divests people from their social characteristics. For the Byzantine State the attitude towards prisoners of war as it was inherited from the Roman world, began to change due to the influence of Christianity and the reality that was shaped from

36 The Taktika of Leo VI. Text, Translation and Commentary, ed. G. Dennis, [CFHB 49] Washington 2010, const.16, par.9.

37 Sophia Patoura, (1944) The Prisoners of War as agents of Communication and Information (4th-10th c.), Athens.

38 The story is narrated by Al-Ṭabarī, The History of al-Tabari, (trans. coment.) F. Rosenthal et als., 18 vols, Albany 1985-1998. 
the appearance of new enemies. The conversion of prisoners into slaves was a general rule for the neighboring foes, as was in fact the case with the Byzantines. Between Byzantium and the Arabs, religious dichotomy was also political, but, in the issue of slaves and free civilians, the two states had a similar approach. Byzantium was trying to take back the soldiers and citizens who fell into the hands of the Arabs as captives, considering them free and not slaves, with the same also applying to the opposite side. The numerous Byzantines under captivity that could be liberated (through an exchange or ransom), killed or could stay with the opponent, created new conditions that the Byzantine State tried to resolve also through legislation ${ }^{39}$. The byzantine law was ready, under conditions, to give back to free Byzantines their place ${ }^{40}$. It is true that simple soldiers were more likely to become prisoners of war. Indeed, military men had to have shown bravery before they were captured, demonstrating that they had not chosen a disgraceful enslavement over the glorious death for the homeland ${ }^{41}$.

The following reference to examples can be helpful to clarify the different standards. On August 15, 838, caliph Al-Mu'tasim, to avenge the occupation of Sozopetra by the Byzantine army of Theophilus, besieged and destroyed Amorion. The invasion was called the Falling of the falls by Abū-Tammām in a poem describing the tragedy. Experienced soldiers had undertaken the city's defense: the strategos (general) of the thema of Anatolikon patrician Aetios, o domestikos of the Excubita and protospatharios Theophilos, o drouggarios of the Vigla patrician

39 In my doctoral thesis I elaboreate this subject giving also an exesive bibliography : Marilia Lykaki, Les prisonniers de guerre dans l'Empire Byzantin (VIe-XIe s.): L'Église, l'État, la diplomatie et la dimension sociale, PhD diss., National and Kapodistrian University of Athens/ École Pratique des Hautes Études, Athens, 2016. Accessed 18 August 2017. Digital publication: http:// thesis.ekt.gr/thesisBookReader/id/37409. (hereafter : Lykaki, "Les prisonniers de guerre".

40 M. Canard, (1956), Quelques «à-côté», de l'histoire des relations entre Byzance et les Arabes, in Studi medievali in onore di Giorgio Levi Della Vida, Roma, p. 98-119 [rep. In (1973), Byzance et les Musulmans du Proche Orient, Variorum Reprints, London, XV] gives a list of prominent emissaries on behalf of both the Arab caliphs and the Byzantine emperors with the task of exchanging prisoners.

P. Dockès, (1979), La libération médiévale, Paris 1979, p.10-14. 
Baboutzikos and the domestikos of the Hikanatoi or strategos of the Boucellarii protospatherios Theodoros Krateros who was in charge of a unit of 3.000 soldiers $^{42}$.

Byzantine and Arabic sources describe the massacre of the city's men and the capture of women and children. Byzantine sources do not fail to name the many prominent prisoners who were arrested, referring to officials and generals and, in fact, providing the names of patricians Kallistos Melissenos tourmarche of Koloneia ${ }^{43}$, Konstantinos Vavoutzikos, protospatharios Theodoros Krateros, dromeus Vassoi and patrician Theofilus ${ }^{44}$. They are the people who led the forty-two-martyr phalanx ${ }^{45}$. The majority of the prisoners were sold on the spot at slave-markets, yet prominent citizens and Byzantine officials, such as those mentioned above, were transferred to Tarsus, where they awaited an exchange (allagion) with the Arabs captured by the Byzantines, which took place on September 16, $845^{46}$. The exchange did not include the high-ranking officials, 42 in total, who, after being imprisoned in Tarsus for seven years, were transferred to Samarra, the capital of the caliphate, where they would decide whether to convert to Islam or to choose execution. The distinction between prominent or not by the Mu'tasim is clear, as he did not hesitate to order the exemplary execution of 6,000 Byzantine prisoners - ordinary soldiers - because a small group had escaped while killing a few Arab soldiers. Prominent military men who did not embrace Islam did not escape the hardships of capture and were eventually executed ${ }^{47}$. This execution, however, is not

42 F. Winkelmanns et als, Prosopographie der mittelbyzantinischen Zeit, vol. 1-5, (1998-2003) years 641-867 and (2013) years 867 -1025), Berlin Brandenburg (hereafter: PmbZ), no. 7679.

$43 \quad P m b Z$, no. 3606

44 Skylitzes, p. $78_{35-38}$. Also see Martyrion (text B), in Skazania o 42 amoriiskich mučenikach, ed. B. Vasilievskij - P. Nikitin, (Mémoires de l'Académie Impériale des Sciences de St. Pétersbourg, VIIIe Série, vol 7, nº 2), St. Pétersbourg 1905, p. $29_{29-35}$.

45 Skylitzes, p. $75_{39-40}$; Symeonis Magistri et Logothetae Chronicon, ed. St. Wahlgren [CFHB 44], Berlin-New York 2006 (hereafter: Symeon Magistros), p. $227_{240-248}$.

46 The exchange was taking place in the Lamos river, not far from Tarsus.

47 Athina Kolia-Dermitzaki, (2002) The Execution of the Forty-two Martyrs 
the usual practice and is attributed to a demonstration of power, retaliation and symbolism ${ }^{48}$.

According to the Martyrion that narrates their martyrdom, the Arabs sought to break the physical and moral strength of the Byzantine soldiers through the nightmarish conditions of their imprisonment. The last blow that would shatter their valor was their belief, which they were invited to renounce in return for their freedom. Even the method of execution was recorded in the context of the policy of the then caliph Al-Wāthik, mainly on religious issues. News of the execution was widely spread, so that a large crowd of Muslims and Christians gathered to watch, while the presence of the caliph himself conveyed particular significance. The 42 eminent byzantine officers were declared martyrs a year after their martyrdom ${ }^{49}$.

Our knowledge of the tragic consequences is evidenced by the text of monk Evodius ${ }^{50}$. Writing a text intended to praise the saints entails the weakness of exaggeration and the subjective narration of the events. Undoubtedly, however, it is a voice of the time. With regard, in fact, to the hagiological texts praising martyrs of the early centuries by giving them superhuman courage, the martyrdom of the forty-two martyrs of Amorion places the protagonists closer to their human dimension ${ }^{51}$.

Christian teaching has highlighted male characteristics, such as restraint, the bending of wrath and passions. The "male" identity was given not only through the participation in war but also through restraint

of Amorion: proposing an interpretation, Al-Masāq 14/2, p. 141-162.

Lykaki, Les prisonniers de guerre, p. 265-281.

49 The texts do not refer to Aetios, general of the Anatolikon, who was executed almost a year after his captivity.

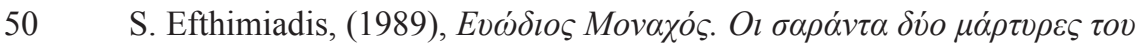
Auopíov, Athens, p. 31. Also see Chronographiae quae Theophanis Continuati nomine fertur libri I-IV, ed. M. Featherstone - J. Signes Codoñer [CFHB 53], Berlin 2015 (hereafter: Theoph. Cont., Featherstone - Signes Codoñer), p. $188_{22}$ $-192_{32}$.

51 Theoph. Cont., Featherstone - Signes Codoñer, p. $166_{16-21}$; Symeon Magistros $227_{241^{-}}{ }_{248}$. For the different versions of the texts see D. Thomas Barbara Roggema (eds), (2009), Christian-Muslim Relations. A Bibliographical History, v. 1 (600-900), Leiden/Boston, p. 846 and A. Kazhdan, (1986), Hagiographical Notes, Byzantion 56 (1986), p. 148-170. 
and endurance; through the toil in private and public life with the "fights" of the body, spirit and emotions. The body becomes a battlefield and highlights the virtues. The fact that restraint has an essentially masculine structure leads to another consequence: the lack of restraint points to a passive attitude associated with femininity ${ }^{52}$.

In the whirl of the conflicts of the tenth century, an era of prosperity for the Byzantium, the self-denial of the Emperor's and Christianity's soldiers was overstated ${ }^{53}$. The violence of war, which in its "just" form was legalized by the Byzantine State, was broadly justified and incorporated into ecclesiastical rhetoric ${ }^{54}$. The honorary place of "military" saints ${ }^{55}$ is evident in the texts but even more so in $\operatorname{art}^{56}$. In addition, there are

52 Michel Foucault, (1987), History of Sexuality, vol. 2. The Use of Pleasure, trans. R. Hurley, New York, 1987.

Although it is essentially a praise of military capabilities and imperial policy, the poem by Theodosius the Deacon and his poem "The Siege of Crete", ed. N. Panagiotakes, (1960) [Kritiki Istoriki Vivliotiki 2], Herakleion, vividly describes the cruelties of Nikephoros Phokas' army when retaking the island. His request for the sanctification of his soldiers foreshadows the future western crusade ideology, according to A. Ducellier, (1971), Miroire de l'Islam. Musulmans et Chrétiens d'Orient au Moyen Age (VIIe-XIe siècles), Paris, p. 238-239. See also I. Stouraitis, (2012), 'Just War' and 'Holy War' in the Middle Ages: Rethinking Theory through the Byzantine Case-Study, Jahrbuch der Österreichischen Byzantinistik 62, p. 227-64.

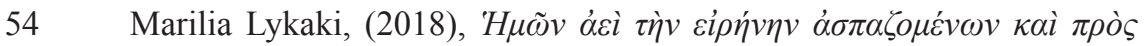

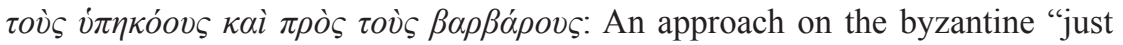
war" through cases from the Middle Byzantine Era, $\sigma \tau \mathrm{o}$ : A. Ampoutis et als (eds), Violence and Politics: Ideologies, Identities, Representations, Newcastle upon Tyne, p. $395-408$.

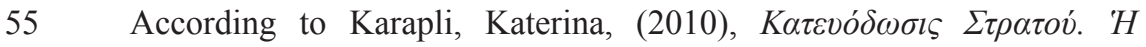

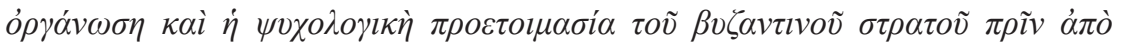

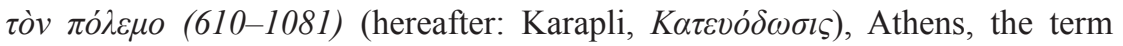
designates saints that had served in the army before their sanctification which came only after their death. Since the tenth century, they have been promoted to protectors of the empire and contributors to victory.

56 St Theodore the recruit, one of the four patron saints of soldiers along with saints Demetrios, Merkourios, Prokopios and George are depicted in mosaics, frescos, coinage, seals, illustrations of manuscripts, flags, crowns and

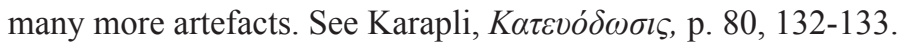


several devotionals dedicated to the military operations of the Byzantine imperial troops ${ }^{57}$. Through these devotionals, the Church's acceptance of war is expressed as a means of protecting Christians ${ }^{58}$. This achieves the formation of a military masculinity where the male model of the herowarrior is reconciled with that of the hero-saint, protectors of the empire and its inhabitants on earth and in heaven ${ }^{59}$.

On the other hand, the manner of dealing with a captive holding the supreme position must have been proportional to the title. We are referring to Emperor Romanos IV Diogenes, who was captured by the Seljuks during the Battle of Matzikert in 1071. When historians are not content with general aphorisms on the fighting and strategic ability of various persons, they describe war-time events and criticize specific actions. The description of his capture is probably the most representative of the action of emperors in the battlefield. The emperor, therefore, put on his armor,

57 Th. Detorakis- J. Mossay, (1988), Un office byzantin inédit pour ceux qui sont morts à la guerre, dans le Cod. Sin. Gr. 734-735, Le Museon, Révue d'études orientales 101, p. 183. Before this office there is another of the ninth century concerning the expedition of the army, see A. Pertusi, (1984), Una acolouthia militate inedita del X secolo, Aevum 22, p. 145-168. In addition, in the tenth century is written an office in praise of the emperor Nicephorus Phokas, see Petit L., (1904), Office inédit en l'honneur de Nicéphore Phocas, Byzantinische Zeitschrift 13, p. 398-420.

58 Kolia-Dermitzaki, Athina, (1991), The Byzantine "Holy War": The Idea and Propagation of Religious War in Byzantium. Historical Monographs 10, Athens, p. 252-253; Kolia-Dermitzaki, Athina, (2012), 'Holy War' in Byzantium Twenty Years Later: A Question of Term Definition and Interpretation, in J. Koder and I. Stouraitis (eds), Byzantine War Ideology Between Roman Imperial Concept and Christian Religion. Akten des Internationalen Symposiums (Wien 19.-21. Mai 2011), [Österreichische Akademie der Wissenschaften, Denkschriften der Philosophisch-HistorischeKlasse 452], Vienna, p. 121-132.

59 The notion of religious "military" struggle and captivity is already expressed by St Paul. The Saint and his companions that are arrested for their action are called by him co-captives, co-soldiers and prisoners of war because they fight for christianity and the salvation of humans. salamito J.- M., (1999), ¿YNAIXMA $\Omega$ TOI: les «compagnons de captivité » de l'apôtre Paul, in A. Chauvot - M. Matter $\kappa \alpha \mathrm{l}$ C. Bertrand-Dagenbach (eds), Carcer I : prison et privation de liberté dans l'antiquité classique. Actes du colloque de Strasbourg (5 et 6 décembre 1997), Paris, p. 191-210. 
raised his sword against the enemies, killed many, and put many to flight. As an expert in military and war-time events, and defying the dangers, he put up fierce resistance. But, then, those who were fighting against him, recognized him and encircled him. Wounded, he slid off his horse and was captured $^{60}$. The Emperor of the Romans was led as a war-captive to the enemy and his troops dispersed. Few were those who escaped. Most either passed by the edge of the sword or were captured. For the latter, one cannot assume it ended well. The sultan, however, in a spirit of friendship and sympathy, let Romanus go, to return to his homeland ${ }^{61}$. The narration of Michael Attaleiates is particularly interesting, as he recounts the incident by mentioning that Romanos was treated very well by the sultan. In fact, in a dialogue between the two men, the sultan asked the Byzantine emperor what he would do if he had captured him. Romanos allegedly replied that he would torture his captive and the sultan responded that he would not imitate his cruel and harsh manner. And, indeed, he seems to have treated his opponent with respect for his rank and position. Instead of temporary revenge, he chose to take advantage of the favorable conditions offered by this capture, and so making a truce and in peaceful conditions... they separated $^{62}$. According to Attaleiates, both buried their dead, and then the sultan let Romanos return to his homeland, taking with him all the Byzantine soldiers and ambassadors he had asked for ${ }^{63}$.

After all, what is the ideal male role model for a soldier? A positive conception of a purified idea of the soldier seams to characterize the entire

$60 \quad$ Kekaumenos, Strategikon, p. $282_{22}$; Attaleiates, Historia, p. $126_{17}-128_{16}$. See also Bryennios, p. $117_{15-22}$ (for the word doryalotos, captured by arms see the dictionary Liddell - Scott, no. 1961). The incident is also described by Aristakès de Lastivert. Récit des malheurs de la nation arménienne, trans. and coment. by M. Canard - H. Berberian, Bruxelles 1973 (hereafter: Aristakès de Lastivert), p. 143-146, who almost heartbreakingly describes the Armenians' suffering. However, he devotes his last chapter to the capture of Byzantine Emperor Romanos IV Diogenes.

61 Aristakès de Lastivert, p. 145. The publishers of the sources note that, according to a Syrian source, Romanos IV was captured by a slave of Greek origin belonging to a Turk and whom the emperor had seen at some point in Constantinople.

Attaleiates, Historia, p. $128_{10-16}$.

Attaleiates, Historia, p. $128_{4-16}$. 
Byzantine period. The soldier assimilates the values of a manhood that is put in the service of society. In fact, his image is revived every time the empire is in danger. Soldiers are given an ideal courage, physical strength, wisdom, ingenuity, courage, sense of justice, self-control, devotion, aversion to money. It could be a soldier like the figure of Digenis Akritis coming from the provincial imaginary, with his moral code and ideals. But even Akritis doesn't have the same heroic characteristics in all textual versions ${ }^{64}$. Close to the positive aspects of military virtues is the perception that aims to stigmatize cowardice. The causes of the army's cowardice are more or less the opposite of the reasons for its bravery. The injury and even worse the death of the head of the body or even the rumor that he was killed have a catalytic effect on the morale of his men, as well as his turn to flee, as Leon the Deacon testifies about the incident of Pastilas' fainting or Skylitzes with the injury of Bardas Skleros. The descriptions given to the cowards correspond to the opposite of the man, to the woman, since for the writers what is not masculine is feminine. They also characterize the enemy in order to show more clearly the opposition to the Byzantine bravery. Porphyrogenitus reminds, for example, his soldiers that in past campaigns it was like they were fighting against women (ở $\chi \omega \varsigma \pi \rho \grave{s} \varsigma$

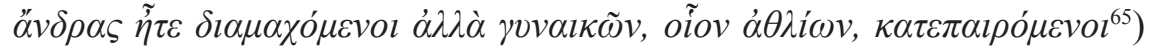
pointing the lack of military virtues of the enemies.

In summary, life as a soldier in the Byzantine army must have varied enormously from century to century as the empire's fortunes changed, and depending on the commanding officers, the type of unit, and so forth. We have very little evidence about individual soldiers, but there is a good deal of information that can be gathered from the wide range of written sources. The masculine ideal of the soldiers absorbed the changes that took place in the Middle Byzantine Era as illustrated in the sources. In addition, the Church, embracing solders among her saints, added new characteristics in manliness. Hence, the concept of manhood in the Middle Ages has expanded since the early days. Two perceptions prevail about bravery, an

64 Digenis Akritis. The Grottaferrata and Escorial versions, ed. E. Jeffreys, Cambridge 1998; c.f. MESSIS Ch., (2006), La construction sociale, les 'réalités' et les représentations de l'identité masculine à Byzance, $\mathrm{PhD}$ thesis, EHESS Paris 2006, 485f.

65 H. Ahrweiler, (1967), Un discours inédit de Constantin VII Porphyrogénète, Travaux et Mémoires 2, 397.5-6. 
aggressive archetype that elevates the pure values of masculinity and finds a response in heroic figures; and a manhood that obeys the social life of the time and corresponds to the type of the faithful man.

The study of byzantine masculinity is a question with serendipitous ramifications that deserves further investigation, within contexts also other than that of warfare but always in grounded social frames of experience and in different periods of Byzantine Empire's more than thousand-year history.

\section{BIBLIOGRAPHICAL REFERENCES}

\section{Primary sources}

H. AHRWEILER, (1967), Un discours inédit de Constantin VII Porphyrogénète, Travaux et Mémoires 2 393-404.

AL-T ABARĪ, The History of al-Tabari, (trans. - coment.) F. Rosenthal et als., 18 vols, Albany: SUNY Press, 1985-1998.

ARISTAKES DE LASTIVERT. Récit des malheurs de la nation arménienne, trans. and coment. by M. Canard - H. Berberian, Bruxelles: Ed. de Byzantion 1973.

DIGENIS AKRITIS. The Grottaferrata and Escorial versions, ed. E. Jeffreys, Cambridge: Cambridge University Press, 1998.

IOANNES SKYLITZES, ed. Thurn Ioannis Skylitzae Synopsis Historiarum, [CFHB 5], Berlin-New York: DeGruyter 1973.

CHRONOGRAPHIAE QUAE THEOPHANIS CONTINUATI NOMINE FERTUR LIBRI I-IV, ed. M. Featherstone - J. Signes Codoñer [Corpus Fontium Historiae Byzantinae 53], Berlin: DeGruyter 2015.

DAS STRATEGIKON DES MAURIKIOS, ed. G.T. Dennis, trans. E. Gamillscheg [CFHB, 17], Vienna: Österreichische Akademie der Wissenschaften, 1981.

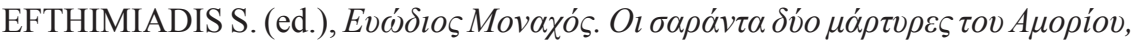
Athens: Akritas, Nea Smyrne 1989.

EUSTATHIUS OF THESSALONIKI, ed. St. Kyriakides, Eustazio di Thessalonica, La espugnazione di Thessalonica [Insituto Siciliano di Studi Byzantini e Neoellenici, Testi e Monumenti, Testi 5], Palermo: Istituto siciliano di studi bizantini e neoellenici, 1961.

IOANNES CAMINIATES, ed. G. Böhlig, Ioannis Caminiatae De expugatione Thessalonicae [CFHB 4], Berlin-N. York: DeGruyter, 1973. 
GEORGE PACHYMERIS, ed. A. Failler, Georges Pachymérès Relations Historiques, IV Livres X-XII [CFHB 24/4], Paris: Institut Français d'Études Byzantines, 1999, vol. IV.

KEKAUMENOS, Strategikon, ed. G. Litavrin, Sovety i rasskazy Kekavmena: pouchenie vizantiǔskogo polkovodtca XI veka, Saint-Pétersbourg: Aletejja 2003.

MARTYRION (text B), in Skazania o 42 amoriiskich mučenikach, ed. B. Vasilievskij - P. Nikitin, [Mémoires de l'Académie Impériale des Sciences de St. Pétersbourg, VIIIe Série, vol 7, n² 2], St. Pétersbourg: Akad. Nauk 1905.

MICHAEL ATTALIATES, ed. Th.E. Tsolakis, Michaelis Attaliatae Historia [CFHB 50], Athens: Academia Atheniensis, 2011.

NICETAS CHONIATES, ed. J. A. van Dieten, Nicetae Choniatae Historia [CFHB 11], Berlin - New York: De Gruyter 1975.

NICHOLAS I, Patriarch of Constantinople, Letters, ed. R. J. H. Jenkins - L. G. Westerink [CFHB 6], Washington D.C.: Dumbarton Oaks Center for Byzantine Studies, 1973.

NOVELLAE ET AURAE BULLAE IMPERATORUM POST JUSTINIANUM, J. Zepos and P. Zepos (ed.) (p. C.E. von Z. Lingenthal), Jus Graecoromanum I, Aalen: Scientia Verlag, 1962, Novella VIII.

PETIT L., (1904), Office inédit en l'honneur de Nicéphore Phocas, Byzantinische Zeitschrift 13, 398-420.

SYMEON MAGISTROS, ed. St. Wahlgren, Symeonis Magistri et Logothetae Chronicon [CFHB 44], Berlin-New York: De Gruyter, 2006.

THE TAKTIKA OF LEO VI. TEXT, TRANSLATION AND COMMENTARY, ed. G. Dennis, [CFHB 49] Washington: Dumbarton Oaks, 2010.

\section{Secondary literature}

AHRWEILER H. (1966), Byzance et la mer, Paris: Presses Universitaires de France.

BLOCH M., (2006), Apologie pour l'histoire ou métier d'historien, in An. Becker

- E. Bloch (eds), Marc Bloch. L'Histoire, la Guerre, la Résistance, Paris: Gallimard.

CANARD M., (1956), Quelques «à-côté», de l'histoire des relations entre Byzance et les Arabes, in Studi medievali in onore di Giorgio Levi Della Vida, Roma: Instituto per l'Oriente, 98-119 [rep. in (1973) Byzance et les Musulmans du Proche Orient, London: Variorum Reprints, XV]

CASEY D., (2013), The Spiritual Valency of Gender in Byzantine Society, in B. Neil - L. Garland (eds.), Questions of Gender in Byzantine Society, Surrey: Routledge. 
CHEYNET J.-Cl., (1991), La politique militaire byzantine de Basile II à Alexis Coirmene, Zbornik Radova, 29-30, 61-74.

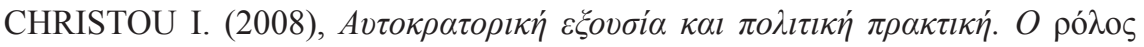

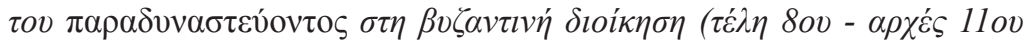
$\alpha \iota \omega ́ v \alpha)$, Athens: Herodotos.

Christian-Muslim Relations. A Bibliographical History, v. 1 (600-900), (2009), ed. D. Thomas - Barbara Roggema, Leiden/Boston: Brill.

CONNELL R. W., (1995), Masculinities, Cambridge.

DOCKÈS P., (1979), La libération médiévale, Paris: Flammarion.

DETORAKIS Th. -MOSSAY J., (1988), Un office byzantin inédit pour ceux qui sont morts à la guerre, dans le Cod. Sin. Gr. 734-735, Le Museon, Révue d'études orientales 101, 183-211.

DUCELLIER A., (1971) Miroire de l'Islam. Musulmans et Chrétiens d'Orient au Moyen Age (VIIe-XIe siècles), Paris: Julliard.

FOUCAULT M., (1987), History of Sexuality, vol. 2. The Use of Pleasure, trans. R. Hurley, New York: Pantheon.

GILMORE D.D., (1990), Manhood in the Making: Cultural Concepts of Masculinity, New Haven: Yale University Press.

JAMES L. (ed.), (1997), Women, Men, and Eunuchs. Gender in Byzantium, London - New York: Psychology Press.

HALDON J., (2014), Byzantium at War (AD 600-1453), Oxford: Osprey Publishing.

J. HALDON, (1999), Warfare, State and Society in the Byzantine World 565-1204 [Warfare and History] London: Taylor \& Francis.

HALDON J., (1979), Recruitment and Conscription in the Byzantine Army, c.550950. A Study on the Origins of the Stratiotika Ktemata [Österreichische Akademie der Wissenschaften, philos. - hist.Klasse, Sitzungsberichte, 357], Wien: Österreichischen Akademie der Wissenschaften.

HALDON J., C. AVERIL., (1995), Seventh-Century Continuities : the Arab and the "Thematic Myth", in: States, Resources, Armies [The Byzantine and Islamic Near East, 3 /Studies in Late Antiquity and Early Islam, 1], Princeton: Darwin Press, 379-423.

HARVEY K. - SHEPARD Al., (April 2005), What Have Historians Done with Masculinity? Reflections on Five Centuries of British History, circa 1500-1950, Journal of British Studies 44, 274-280.

KAZHDAN A., (1986), Hagiographical Notes, Byzantion 56, 148-170.

KAZHDAN A. - Wharton Epstein A., (1985), Change in Byzantine Culture in the Eleventh and Twelfth Centuries, Berkley - Los Angeles: University of California Press. 
KAZHDAN A., (1984), "The Social Views of Michael Attaleiates” in: A. Kazhdan (ed.), S. Franklin (colab.), Studies on byzantine Literature of the eleventh and Twelfth Centuries, Cambridge: Cambridge University Press, 23-86.

KOLIA-DERMITZAKI A., (2002), The Execution of the Forty-two Martyrs of Amorion: proposing an interpretation, Al-Masāq 14/2, 141-162.

KOLIA-DERMITZAKI A., (2012), About Virtue and Vice. The Byzantine Officials in Historiographical Sources, Part I, Political and Military Officials of the 9th and 10th Centuries, Athens: Herodotos.

KOLIA-DERMITZAKI A., (2012), 'Holy War' in Byzantium Twenty Years Later: A Question of Term Definition and Interpretation, in J. Koder and I. Stouraitis (eds), Byzantine War Ideology Between Roman Imperial Concept and Christian Religion. Akten des Internationalen Symposiums (Wien 19.-21. Mai 2011), [Österreichische Akademie der Wissenschaften, Denkschriften der Philosophisch-HistorischeKlasse 452] Vienna: VÖAW.

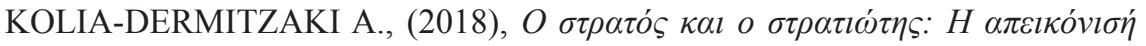

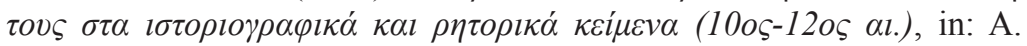
Kolia-Dermitzaki, V. Seirinidou, Sp. Ploumidis (ed.), M. Lykaki (colab.), Histories of War in South-Eastern Europe: An Approach in the Longue Durée. A centenary since the Balkan Wars of 1912-13. International Scientific Conference of the Department of History and Archaeology (7-9 November 2013), Athens: Herodotos.

KOLIA-DERMITZAKI A., (1991), The Byzantine "Holy War": The Idea and Propagation of Religious War in Byzantium [Historical Monographs 10] Athens: Historical Publications ST. D. Basilopoulos, 252-253.

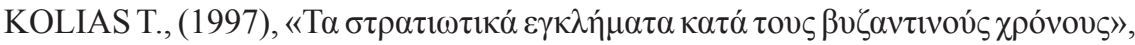

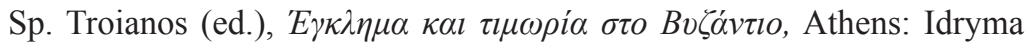
Goulandri-Horn, 295-316.

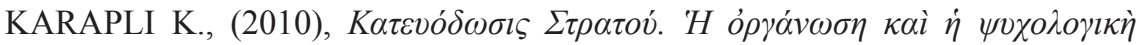

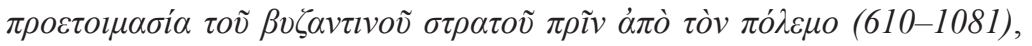
Athens: Herodotos.

KUEFLER M., (2001), The manly eunuch : masculinity, gender ambiguity, and Christian ideology in late antiquity, Chicago: University of Chicago Press.

LILIE R.-J., (2013), Die byzantinische Gesellschaft im Spiegel ihrer Quellen, Zbornik radova Vizantološkog instituta 50, 959-968.

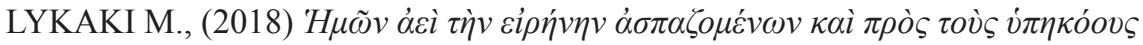

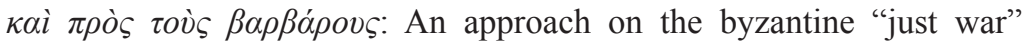

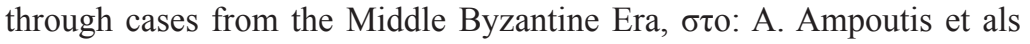
(eds), Violence and Politics: Ideologies, Identities, Representations, Newcastle upon Tyne: Cambridge Scholars, 395 - 408. 
LYKAKI M. (2016), "Les prisonniers de guerre dans l'Empire Byzantin (VIeXIe s.): L'Église, l'État, la diplomatie et la dimension sociale." $\mathrm{PhD}$ diss., National and Kapodistrian University of Athens/ École Pratique des Hautes Études. Accessed 18 August 2017. Digital publication: http:// thesis.ekt.gr/thesisBookReader/id/37409.

LYKAKI M. -VASSILOPOULOU N., (2018), Mercenaries of Byzantium: Their role during the transition from the Middle to the Late Byzantine era, in: A. Kolia-Dermitzaki, V. Seirinidou, Sp. Ploumidis (ed.), M. Lykaki (colab.), Histories of War in South-Eastern Europe: An Approach in the Longue Durée. A centenary since the Balkan Wars of 1912-13. International Scientific Conference of the Department of History and Archaeology (7-9 November 2013), Athens: Herodotos, 160-175.

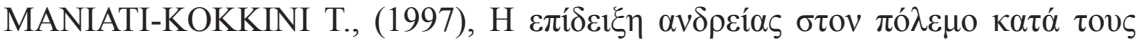

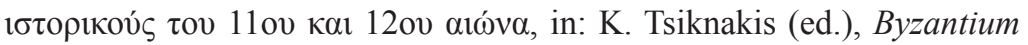

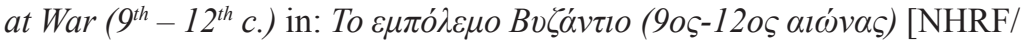
IBR, International Symposium 4], Athens: National Hellenic Research Foundation. Institute for Byzantine Research, 239-259.

MESSIS Ch., (2014), Les eunuques à Byzance, entre réalité et imaginaire [Dossiers Byzantins 14] Paris: Centre d'études byzantines, néo-helleniques et sudest européennes.

MESSIS Ch., (2006), La construction sociale, les 'réalités' et les représentations de l'identité masculine à Byzance, $\mathrm{PhD}$ thesis, EHESS - Paris.

MYLES-MCDONNELL A., (2006), Roman manliness: virtus and the Roman Republic, Cambridge: Cambridge University Press.

PATOURA S., (1994), The Prisoners of War as agents of Communication and Information (4th-10th c.), Athens: National Hellenic Research Foundation. Institute for Byzantine Research.

PERTUSI A., (1984), Una acolouthia militate inedita del X secolo, Aevum 22, $145-168$.

PERTUSI A., (1958), La formation des thèmes byzantins, in: Berichte zum XI. Internationalen Byzantinisten-Kongress, München: Beck Verlag.

RAGIA E., (2012), The Geography of the Provincial Administration of the Byzantine Empire (ca.600-1200): I.3 Apothekai of Africa and Sicily, Final Notes and Conclusions, Eoa kai Esperia 8, 113-144.

RINGROSE K. M., (2003), The Perfect Servant: Eunuchs and the Social Construction of Gender in Byzantium, Chicago: University of Chicago Press.

SALAMITO J.- M., (1999), इYNAIXMA $\Omega$ TOI: les «compagnons de captivité » de l'apôtre Paul, in A. Chauvot-M. Matter кal C. Bertrand-Dagenbach (eds), Carcer I : prison et privation de liberté dans l'antiquité classique. Actes du colloque de Strasbourg (5 et 6 décembre 1997), Paris: De Boccard. 
STOURAITIS, (2012), 'Just War' and 'Holy War' in the Middle Ages: Rethinking Theory through the Byzantine Case I. -Study, Jahrbuch der Österreichischen Byzantinistik 62, 227-64.

SCOTT J.W., (1986), Gender: A Useful Category of Historical Analysis, American Historical Review, 91 (5), 1053-1075; repr. in (1988), J. W. Scott, Gender and the Politics of History, New York: Columbia University Press, 28-50.

STEWART M., (2014), Some Disputes Surrounding Masculinity as a Legitimate Category of Historical Inquiry in the study of Late Antiquity, Masculinities $1,77-91$.

STEWART M., (2006), Soldier's Life. Early Byzantine Masculinity and the Manliness of War, Byzantina Symeikta 26, 11-44.

SHEPARD J., (1993), The uses of the Franks in 11th century Byzantium", AngloNorman Studies 15, 280-281.

TAFT R.F., (1998), Women at Church in Byzantium: Where, When - And Why?", Dumbarton Oaks Papers, 52, 27-87; repr. in (2001), R.F. Taft, Divine Liturgies: Human Problems in Byzantium, Armenia, Syria and Palestine, Aldershot: Ashgate-Variorum.

THEOTOKIS G., (2012), Rus, Varangian and Frankish mercenaries in the service of the Byzantine emperors (9th - 11th c.). Numbers, organization and battle tactics in the operational theatres of Asia Minor and the Balkans", Byzantina Symmeikta 22, 125-156.

TOUGHER S.F, (2013), Bearding Byzantium: Masculinity, eunuchs and the Byzantine life course, in: N. Bronwen and L. Garland, Lynda (eds), Questions of Gender in Byzantine Society, Farnham: Routledge, 153-166. VLYSSIDOY V. et als, (1998), Asia Minor and Its Themes: Studies on the Geography and Prosopography of the Byzantine Themes of Asia Minor (7th-llth Century). In Greek [Research Series, 1], Athens: National Hellenic Research Foundation, Institute for Byzantine Research,

WINKELMANNS F. et als, Prosopographie der mittelbyzantinischen Zeit, vol. 1-5, (1998-2009) years 641-867, and (2013) years 867-1025, Berlin Brandenburg: DeGruyter.

ZUCKERMAN C., (2005), Learning from the Enemy and More: Studies in "Dark Centuries" Byzantium", Millennium 2, 79-135. 